FACTA UNIVERSITATIS

Series: Physical Education and Sport, Vol. 18, No 3, 2020, pp. 577 - 588

https://doi.org/10.22190/FUPES201111056K

Research article

\title{
THE CONNECTION BETWEEN THE AGILITY OF ADOLESCENT SOCCER PLAYERS AND THEIR BODY COMPOSITION
}

\author{
UDC 796.332.012.23:611-053.6
}

\author{
Miklós Koltai ${ }^{1}$, Ádám Gusztafik ${ }^{1}$, Katalin Nagyváradi ${ }^{1}$, \\ Bálint Szeiler ${ }^{1}$, Szabolcs Halasi ${ }^{2}$, Josip Lepeš ${ }^{3}$ \\ ${ }^{1}$ Faculty of Education and Psychology, Institute of Sport Sciences, Eötvös Lóránd \\ University, Szombathely, Budapest, Hungary \\ ${ }^{2}$ Teacher Training Faculty in Hungarian in Subotica, University of Novi Sad, \\ Subotica, Serbia \\ ${ }^{3}$ Mihály Marcell Special Pedagogical Research Group, Gál Ferenc University, \\ Szeged, Hungary
}

\begin{abstract}
The aim of this study is to determine body composition (BC) factors that influence agility among adolescent soccer players $(N=66)$, in U14, U16, U18 soccer teams of the Topola Sport Club. Agility tests (Dribbling test, Illinois test), Inbody 720 instrument measuring the BC, and Oxa Starter infrared timing gate instrument measuring speed the agility were used. Data are processed by the IBM SPSS Statistics 25 software. In addition to descriptive statistics, a correlation matrix analysis, linear regression and one-way analysis of variance (ANOVA) were also applied ( $p<0.05)$. A moderate correlation between agility with a ball and without a ball $(r=0.595)$ is determined as well as between agility and BC parameters: Skeletal Muscle Mass, Intracellular Water Mass, Protein Mass, Mineral Mass ( $r=-0.453,-0.454,-0.453$, 0.417 , respectively) while the correlation between agility and Height, Mass, Body Mass Index, Right Leg Lean Mass, Left Leg Lean Mass, Extracellular Water Mass is less than moderate $(r=-0.318,-0.329,-0.276,-0.332,-0.330,-0.374$, respectively). A slight correlation is determined between agility with a ball and $B C$ variables. No correlation was determined between Agility and Body Fat Mass. The influence of BC on agility is lower than expected. Using the scientific based approach and measurements, a complex exercise plan can be made for players and in this way young soccer players can be trained by using tailor-made and post-specified coaching methods.
\end{abstract}

Key words: Agility, Adolescents, Soccer, Body Composition.

Received November 11, 2020 / Accepted December 19, 2020

Corresponding author: Miklós Koltai

Faculty of Education and Psychology, Eötvös Lóránd University, Szombathely, Egyetem tér 1-3, H-1053 Budapest, Hungary

Phone: +36-1-411-6500 • E-mail: koltai.miklos@ppk.elte.hu 


\section{INTRODUCTION}

Agility, a Latin word, has the everyday meaning of: modesty, dexterity, alertness, vitality, speed, and mobility (Bakos, 2007). Agility is most noticeable in sports with open motor skills, for example in various ball games and in combat sports. In modern soccer, agility is considered to be the key to success (Koltai, 2018). In sports with open motor skills, straight-line running occurs rarely (Bangsbo \& Mohr, 2012); on the other hand, random redirection or change of direction can be observed constantly (Goodman, 2008). There are several definitions in the international literature, but they all agree that it includes a direction of motion changed at maximum speed (Bloomfield et al., 1994). Agility is often characterized by rapid start, stop (Gambetta, 1996), and explosiveness (Baker \& Nance, 1999). According to Sheppard and Young (2006), agility is defined as "a rapid physical activity that involves a change in speed and direction by a stimulus". In simplified terms, it is an unpredictable change in speed or direction (Draper \& Lancaster, 1985). The ability to accelerate and decelerate with a change of direction is usually called agility. It is a rapid whole-body movement that involves a change in speed or direction in response to an environmental stimulus. Based on this, agility is much more complex in sports games, consisting of perceptual, decision-making, and change of direction components (Young, Dawson, \& Henry, 2015). There are many factors that influence this speed, for example, straight-line sprinting (SS), leg strength, and reactivity.

In a soccer match, a change of direction occurs every 2 to 4 seconds, which means that it occurs 1200 to 1400 times throughout the match (Sporiš, Jukić, Ostojić, \& Milanovic, 2009). Through the development of finer GPS systems, these changes of direction have become the focus of match analysis (Barnes, 2016). Running performance during soccer matches requires an extensive amount of technical, tactical, psychological and physical effort, including aerobic and anaerobic energy processes, muscular strength, flexibility and agility (Chamari et al., 2004). During a game, low and high intensity periods alternate periodically with short sprints, jumps, and directional changes (Rouissi et al., 2006). The nature of the agility, its characteristics and its connection to other abilities lead to contradictions. The relationship between agility and speed was not clearly substantiated (Young, Hawken, \& McDonald, 1996; Buttifant, Graham, \& Cross, 2002; Condello, Schultz, \& Tessitore, 2013; Milanović et al., 2014). There was no direct relationship between leg strength and agility (Webb \& Lander, 1983; Young, James, Montgomery, 2002). Some authors associate agility with coordination skills (Katics, 2015). Agility performance may vary at different training levels, but not necessarily those in the highest level achieve the best results (Koltai et al., 2016). Overall, it can be stated that the relationship between agility and different endurance abilities or traditional coordination abilities cannot be clearly demonstrated (Sever \& Zorba, 2017).

Agility is independent of the positions occupied in the game (Ruas et al., 2015; Franks \& Hughes, 2016), but selecting a position may be significantly influenced by genetic predispositions (Reilly, Bangsbo, \& Franks, 2000; Rebelo et al., 2013; Perroni, Vetrano, Camolese, Guidetti, \& Baldari, 2015). However, most research does not show significant differences in the selection of players for a given position based on their anthropometric, physical or mental characteristics (Coelho, Figueiredo, Cumming, \& Malina, 2010; Fiorilli et al., 2013; di Cagno et al., 2014; Deprez et al., 2015).

In light of the abovementioned, it seems that the two types of agility, agility without a ball and agility with a ball are increasingly seen as distinct, independent, complex 
abilities (Koltai et al., 2017). Both agility without a ball and agility with a ball are important in soccer for all players in any position (Németh, 2015). Agility without a ball, in terms of its structure of movement, is mostly related to horizontal, defensive roles, while agility with a ball plays an important role in vertical, offensive movements.

By examining the validity of the various agility tests, researchers tried to determine the most suitable tests for estimating the agility of the players in different positions (Sporiš, Jukić, Milanović, \& Vučetić, 2010; Young \& Willey, 2010).

The performance of young athletes is significantly influenced by their body composition. A number of researchers (Post et al., 1997; Bodzsár \& Susanne, 1998; Beunen, 2003) have concluded that nutrition is a major determinant of children's development. The amount, quality and regularity of energy intake and the frequency of physical activity are key factors during children's development (Szakály, 2008). According to recent research (Németh \& Költö, 2014), the lifestyle of adolescents is characterized by inactivity and unhealthy nutrition. Malnutrition creates a state of deficiency in vital nutrients, altering the body composition of the individual, which causes the individual's physical performance to decline. The body's relative fat content decreases at birth, then increases until puberty and stabilizes in the postpubertal age. However, in recent decades, the amount of adipose tissue has increased in samples of students (Szakály, 2008). According to Lohman (1992), the optimal body fat content for boys who regularly perform physical activity is between $15 \%$ and $16 \%$. The relationship between body composition and physical or physiological performance has been demonstrated from multiple aspects (Prókai et al., 2005; Rowland, 2005; Photiou et al., 2008). In biology and health research studies, the fat to mass ratio is a commonly studied feature, whereas in sports anthropometry, in addition to the amount of fat, the proportion of muscle tissue is also of greater importance (Szakály, 2008). Changes in body composition and physical performance of children and adolescents are closely related (Gyenis, 1975; Eiben \& Pantó, 1981; Farmosi \& Bakonyi, 1987; Mészáros, Othman, \& Szabó, 2001).

According to some estimates, the number of malnourished children and adolescents in Hungary today is between 250000 and 350000 (Mészáros et al., 2001). Proper nutrition also includes regular intake of protein, vitamins and minerals that fully satisfies biological needs.

As a result of normal organic development and workout adaptation, the physique and anthropometric data of athletes of all ages may change significantly. Presumably, players with a lower center of gravity benefit when having to perform quick changes of direction. It would seem evident that athletes with more leg strength are more effective in making quick starts and sudden stops. The role of laterality may manifest in the muscle mass of the two legs.

The aim of this study is to determine body composition factors that influence agility among adolescent soccer players.

\section{METHODS}

\section{Participants}

The participants in this cross-sectional study consisted of soccer players of age groups U14, U16 and U18, from the Topola Sport Club Junior Academy (Bačka Topola, Serbia). The following players (according to their position in the team) took part in the study: 5 goalkeepers, 17 defenders, 25 midfielders and 19 strikers $(\mathrm{N}=66)$. The players participated in 
four training sessions per week and in one match during the weekend. The study was conducted during the winter preparation period.

\section{Variables}

Body mass index (BMI); Right Leg Lean Mass (RLLM); Left Leg Lean Mass (LLLM); Intracellular Water Mass (IWM); the Extracellular Water Mass (EWM); Protein Mass (PM); Mineral Mass (MM).

Internationally standardized agility tests:

- Illinois Change of Direction Speed Test (ICODT)-with and without a ball;

- T-Test*without a ball;

- TDS Dribbling Test-without a ball, and with a ball using the dominant, and subdominant leg.

The tests were done on a hard sport flooring after a standard warm-up. The better result was considered of the two attempts.

\section{Instruments}

The Oxa Starter+ infrared timing gate was used as the measuring instrument for the agility tests.

The gate consists of an infrared antenna-free transmitter and a receiver with an infrared $(950 \mathrm{~nm})$ antenna, integrated with a radio transmission unit. The instrument needs a 9V DC power source, and it has a power consumption of 9 to $20 \mathrm{~mA}$. The system is connected to the computer through an USB port. The measuring device consists of five light gates.

\section{Body composition analysis}

For this study, the InBody 720 (Biospace Co. Inc., Seoul, South Korea) Bioelectrical Impedance Analyzer (BIA) was used (Nagyváradi, 2017).

\section{Data analysis}

The results were encoded, recorded in an Excel table and processed with $I B M{ }^{\circledR}$ SPSS ${ }^{\circledR}$ Statistics 25 software. In addition to descriptive statistics, a correlation matrix analysis, linear regression and one-way analysis of variance (ANOVA) were also applied. The significance was set at the $\mathrm{p}<0.05$ level.

\section{RESULTS}

The study included $\mathrm{N}=66$ young elite soccer players with a span of 6 years in terms of age, split into three age groups (U14, U16, U18). Their average BH was 1.75 meters, with the shortest participant being 1.51 meters and the tallest being 1.98 meters. Their average BM was $64.5 \mathrm{~kg}$ with a standard deviation of $11 \mathrm{~kg}$. The average SMM was $32.39 \mathrm{~kg}$, with a standard deviation of $5.85 \mathrm{~kg}$. BFM had an average of $7.09 \mathrm{~kg}$ with a standard deviation of $3.59 \mathrm{~kg}$. Accordingly, the participants had a low BMI with an average of 20.91. The sample contained 56 right-footed (85\%) and only 10 left-footed players. RLLM averaged $9.16 \mathrm{~kg}$ for right leg, and LLLM averaged $9.09 \mathrm{~kg}$ for left leg. The combined muscle mass of the two legs averaged $18.25 \mathrm{~kg}$ (standard deviation 3.20 
$\mathrm{kg}$ ), IWM averaged $26.38 \mathrm{~kg}$ (standard deviation $4.49 \mathrm{~kg}$ ), EWM averaged $15.68 \mathrm{~kg}$, PM averaged $11.40 \mathrm{~kg}$ (standard deviation $1.94 \mathrm{~kg}$ ), and MM averaged $3.93 \mathrm{~kg}$ (standard deviation $0.67 \mathrm{~kg}$ ).

Table 1 Body composition parameters

\begin{tabular}{|c|c|c|c|c|}
\hline $\mathrm{N}=66$ & Minimum & Maximum & Mean & Std. Deviation \\
\hline Height & 151.00 & 198.00 & 175.09 & 9.20 \\
\hline Body Mass & 37.10 & 86.70 & 64.47 & 10.94 \\
\hline Skeletal Muscle Mass & 18.60 & 45.20 & 32.40 & 5.86 \\
\hline Body Fat Mass & 1.80 & 24.60 & 7.09 & 3.59 \\
\hline Body Mass Index & 15.00 & 25.80 & 20.91 & 2.24 \\
\hline Right Leg Lean Mass & 5.34 & 13.68 & 9.16 & 1.61 \\
\hline Left Leg Lean Mass & 5.32 & 13.55 & 9.09 & 1.60 \\
\hline Right + Left Leg Lean Mass & 10.66 & 27.23 & 18.25 & 3.21 \\
\hline Intracellular Water Mass & 15.80 & 36.20 & 26.38 & 4.49 \\
\hline Extracellular Water Mass & 9.50 & 21.60 & 15.68 & 2.49 \\
\hline Protein Mass & 6.80 & 15.60 & 11.40 & 1.94 \\
\hline Mineral Mass & 2.42 & 5.34 & 3.93 & 0.67 \\
\hline
\end{tabular}

\section{Body parameters by age group}

One-way analysis of variance (ANOVA) applied to SMM, BMI, PM, MM, RLLM, and LLLM showed a statistically significant difference between the average values of the age groups $(\mathrm{p}<0.000)$. Values showed a strict monotonous growth in all cases. BFM also exposed an increase between age groups; however, statistically this is not proven $(\mathrm{p}=0.493)$.
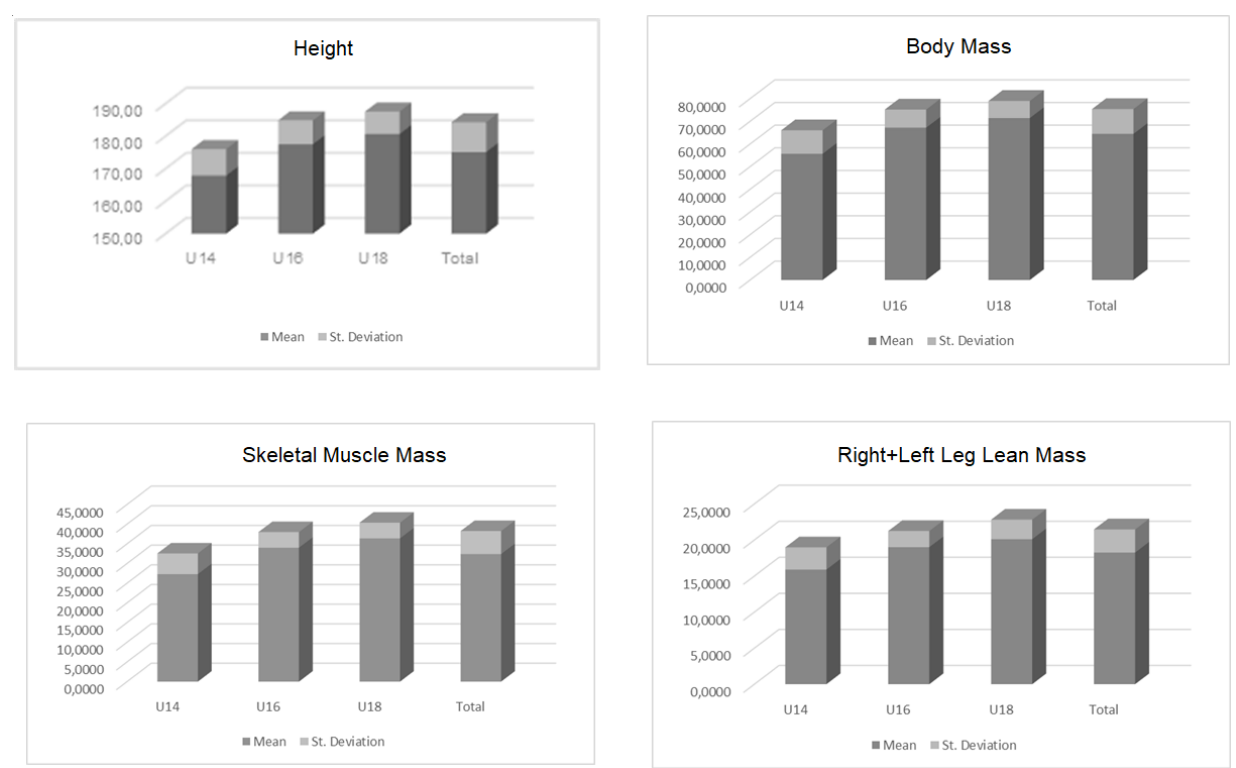

Fig. 1 Body parameters by age group $(\mathrm{p}<0.05)$ 
Analysis of the structure of movements in the agility tests showed that none of the individual movements fully described the characteristics of movements in soccer. Therefore, this study introduced two new complex variables: agility without a ball (AWOB) and agility with a ball (AWB). The AWOB variable was determined by adding up the results a certain player achieved on the Illinois test without a ball, TDS Dribbling Test without a ball, and TTest. The variable thus obtained is the most characteristic of defensive movements. The AWB variable was calculated by adding up the results a certain player achieved on the Illinois Test with a ball drilling on the arbitrary side, the TDS Dribbling Test with the dominant leg, and the TDS Dribbling Test with the subdominant leg. The variable thus obtained is the most characteristic of offensive movements.

A linear regression analysis was used to examine the relationship between the two variables. Each point in the coordinate system represents a player. Players close to the regression line performed consistently in terms of both AWOB and AWB tests. The points near the origin represent the best performing players. A moderate correlation was found between AWOB and AWB (r=0.595; $\mathrm{p}<0.000)$ (Fig. 2).

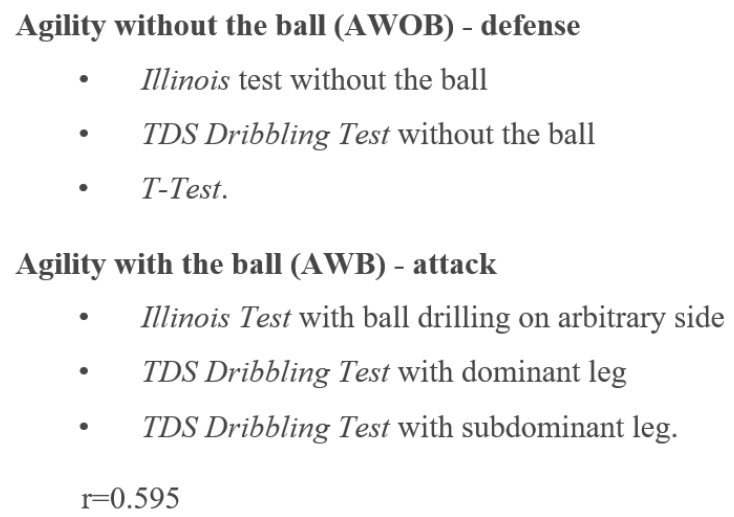

Fig. 2

There was also a moderate correlation between AWB and body composition parameters: SMM, IWM, PM, MM $(-0.453,-0.454,-0.453,-0.417)$. While the following variables show a weaker than average correlation with agility: Height, Mass, BMI, RLLM, LLLM, EWM (-0.318, -0.329, -0.276, -0.332, -0.330, -0.374). There was only a weak correlation between AWB and body type parameters, while no correlation was found between body fat components and agility. The combined agility (hereafter, CAG) index (AWOB+AWB) has a weaker than average correlation with Height, Mass, SMM, BMI, IWM, EWM, PM, MM, R LLM (-0.244, -0.283, -0.365, -0.283, -0.366, -0.344, 0.248 ), while there is no significant correlation with BFM (Table 2). 
Table 2 Correlation between agility indicators and body composition (Pearson)

\begin{tabular}{llllll}
\hline & Height & Mass & SMM & BFM & BMI \\
\hline AWOB & $-.318^{* *}$ & $-.329^{* *}$ & $-.453^{* *}$ & .143 & $-.276^{*}$ \\
AWB & -.167 & -.217 & $-.263^{*}$ & .007 & $-.245^{*}$ \\
CAG & $-.244^{*}$ & $-.283^{*}$ & $-.365^{* *}$ & .060 & $-.283^{*}$ \\
\hline \multicolumn{7}{r}{} & & & & \\
\hline AWOB & IWM & EWM & PM & MM & R+LLLM \\
AWB & $-.454^{* *}$ & $-.374^{* *}$ & $-.453^{* *}$ & $-.417^{* *}$ & $-.331^{* *}$ \\
CAG & $-.264^{*}$ & $-.216^{* *}$ & $-.263^{*}$ & $-.253^{*}$ & -.166 \\
\hline
\end{tabular}

Legend: AWOB-agility without the ball; AWB-agility with the ball; CAG-combined agility; SMM-Skeletal Muscle; BFM-Body Fat Mass; BMI-Body Mass Index; IWM-Intracellular Water Mass; EWM-Extracellular Water Mass; PM-Protein Mass; MM-Mineral Mass; RLLM-Right Leg Lean Mass; LLLM-Left Leg Lean Mass; ${ }^{* *}$-Correlation is significant at the 0.01 level (2-tailed); ${ }^{*}$-Correlation is significant at the 0.05 level (2-tailed).

An examination of the laterality factors (Table 3) revealed that there was a slight difference in the lean muscle mass of the two feet $(r=0.998 ; \mathrm{p}<0.000)$ in the case of the $\mathrm{N}=56$ right-footed soccer players. A weaker than average correlation was found between RLLM and AWOB ( $\mathrm{r}=0.353 ; \mathrm{p}=0.008)$, while no significant correlation was found with AWB. In the case of right-footed players, a strong moderate relationship is found between AWOB and AWB $(r=0.586 ; \mathrm{p}<0.000)$, and a strong correlation with the CAG $(\mathrm{r}=0.819 ; \mathrm{p}<0.000)$. There is an even closer relationship between AWB and the CAG index for right-footed players $(\mathrm{r}=0.945 ; \mathrm{p}<0.000)$.

The $\mathrm{N}=10$ left-footed players in the sample showed a slight difference in lean muscle mass of the two feet $(r=0.999 ; \mathrm{p}<0.000)$. No significant relationship was found between the CAG factors and the muscle mass of the two feet. In the case of left-footed players, there is a strong relationship between AWOB and AWB $(r=0.730 ; p=0.017)$, with a strong CAG index value $(\mathrm{r}=0.833 ; \mathrm{p}=0.003)$. There is an even closer relationship between the AWB and CAG index for left-footed players ( $r=0.986$; $p<0.000)$, (Table 3).

Table 3 Laterality

\begin{tabular}{|c|c|c|c|c|c|}
\hline $\begin{array}{l}\text { Right Dominant Leg } \\
\mathrm{N}=56\end{array}$ & LLLM & RLLM & AWOB & AWB & CAG \\
\hline LLLM & 1 & $.998^{* *}$ & $-.353^{* *}$ & -.159 & -.255 \\
\hline RLLM & $.998^{* * *}$ & 1 & $-.353^{* *}$ & -.158 & -.255 \\
\hline AWOB & $-.353^{* *}$ & $-.353^{* *}$ & 1 & $.586^{* *}$ & $.819^{* *}$ \\
\hline AWB & -.159 & -.158 & $.586^{* *}$ & 1 & $.945^{* *}$ \\
\hline $\mathrm{CAG}$ & -.255 & -.255 & $.819^{* *}$ & $.945^{* *}$ & 1 \\
\hline $\begin{array}{l}\text { Left Dominant Leg } \\
\mathrm{N}=10\end{array}$ & LLLM & RLLM & AWOB & AWB & CAG \\
\hline LLLM & 1 & $.999^{* * *}$ & .009 & -.211 & -.168 \\
\hline RLLM & $.999^{* *}$ & 1 & -.011 & -.246 & -.201 \\
\hline AWOB & .009 & -.011 & 1 & $.730^{*}$ & $.833^{* *}$ \\
\hline AWB & -.211 & -.246 & $.730^{*}$ & 1 & $.986^{* *}$ \\
\hline CAG & -.168 & -.201 & $.833^{* *}$ & $.986^{* *}$ & 1 \\
\hline
\end{tabular}

Legend: LLLM-Left Leg Lean Mass; RLLM-Right Leg Lean Mass; AWOB-agility without the ball;

AWB-agility with the ball; CAG-combined agility; ${ }^{* *}$ - Correlation is significant at the 0.01 level (2-tailed); * - Correlation is significant at the 0.05 level (2-tailed). 


\section{DISCUSSIONS}

The study included $\mathrm{N}=66$ young elite soccer players with a span of 6 years in terms of age, and 2-year period for each age group (U14, U16, U18).

Their physique was proportional. The parameters measured by the InBody720 instrument met the standards expected of athletes of their respective ages (see also Szakály, 2008). The high standard deviation observed in each indicator is a good sign of changes in the body composition of young athletes. Their height varied widely, while their SMM and BFM were proportional to body size and meet the standard (Photiou et al., 2008). Obese athletes were not found in the sample. Conscious nutrition and regular, persistent workouts can further improve their body muscle composition through intense development and allow them to be successful athletes in their adult age (Mészáros et al., 2001). Emphasis should be placed on the nutritional composition ensuring the intake of necessary vitamins, minerals, and protein, as other authors have also suggested (Lohman, 1992; Purcell, 2013). In addition to normal nutrition, it is advised to use appropriate isotonic drinks and nutritional supplements, and to provide young people with adequate fluid intake (Németh \& Költö, 2014). Instead of empty calories in fast food and soft drinks, regular, high-calorie diets should be preferred, taking into account the correct proportion of each ingredient and the number of calories. To this end, it is encouraged to consult with a nutritionist and inform young athletes and their parents.

In case of the most important physical parameters (SMM, BMI, PM, MM, and RLLM), there was a statistically significant difference between the soccer players of a given age group. The constant growth of these values corresponds to biological development and verifies the work done. No significant difference was found in BFM, which indicated that there are deficiencies in the conscious nutrition of athletes.

Based on this study, it can be concluded that agility is an extremely complex ability, as other authors have a similar view (Bloomfield et al., 1994; Buttifant et al., 2002; Bangsbo \& Mohr, 2012), and its connection to other skills and performance components is hard to define (Sheppard \& Young, 2006; Koltai et al., 2016), so it is significance for soccer is quite immense (Radák, 2019). The agility tests AWB or AWOB belong to motor tests organically in the case of young soccer players (Momčilović et al., 2020). their relation with other abilities and the performance component structure are quite difficult to define. There are two kinds of agility and we focused on changing directions in our research (Csáki \& Takács, 2020).

By examining the correlation between AWOB and AWB, it can be stated that in order to progress, athletes need to practice specific, high intensity exercises which include fast starts, changes of direction, and sudden stops (Lacome, Simpson, Cholley, Lambert, \& Buchheit, 2018). Similar conclusions were found in other studies (Condello et al., 2013; Milanović et al., 2014; Koltai et al., 2017). For maximum intensity, AWOB and AWB exercises should be done in combination. The regression graph clearly shows the performance of each player, which can serve as feedback to coaches on how to select players for their positions and how to set up individually differentiated training programs. Similar results were achieved by other researchers (Franks \& Hughes, 2016; Sever \& Zorba, 2017).

In the examined sample, body parameters showed a moderate to weak connection to AWOB and AWB. The poor relationship between AWB and physical indicators suggests that players still have plenty of room for improvement in ball handling techniques. The lack of correlation between CAG factors and BFM indicates deficiencies in sports specific nutrition. 
Examining the laterality factors, it can be concluded that the lean muscle mass of the lower limb of the $\mathrm{N}=56(85 \%)$ right-footed and $\mathrm{N}=10$ left-footed players is proportional in the sample (Rouissi et al., 2006). However, the difference is not significant.

Specific training must be done to ensure that young footballers can handle the ball effectively with both feet as early as possible. This was included in other methodological descriptions as well (Németh, 2015).

The study verified that body composition of soccer players changes significantly with age. A close relationship between CAG indexes and body composition was not demonstrated. No strong, significant relationship was found between agility indicators and lean muscle mass of the dominant foot of young soccer players.

Modern training methods must be used and abilities which influence agility must be emphasized and consciously planned in order to train a successful soccer player.

This ability is the most important element of all ballgames, the development of which requires different kinds of coaching methods in the case of different age groups. Bompa and Carrera (2015) worked out the long-term periodicity of agility to help soccer players do better. The performed agility tests (measuring the ability changing directions), are based on closed mobility. This type lacks decision processes, so one can plan its achievability. The basis of achievement is doing accelerations and decelerations as fast as it is possible. The best thing is when players use both of their feet in the case of agility with a ball. When acquiring this skill the basis is provided by multilateral coaching.

Particular emphasis should be placed on the proper nutrition of the athletes, thus developing a favorable body composition. The basis of quality nutrition is the balance of macro- and micronutrients. Fiber, vitamin and mineral intake is provided by a balanced diet. When producing ATP one uses high quantities of blood sugar and muscle glycogen. As soon as the physical activity is over, one has to start replacing carbohydrates. The replacement of fluids is also essential. There is evidence that athletes who are hydrated can perform better than dehydrated ones (Kiitam et al., 2018). Cooperation between athletes, parents, coaches and sports dieticians is required to do an efficient nutritional program (Steffl, Kinkorova, Kokstejn, \& Petr, 2019).

\section{CONCLUSION}

Using the scientific based approach and measurements a complex exercise plan can be made for players and in this way young soccer players can be trained by using tailormade and post-specified coaching methods. The players who were involved in our research were motivated all the time and they did the tests to help the researchers' work.

\section{REFERENCES}

Baker, D., \& Nance S. (1999). The relation between running speed and measures of strength and power in professional rugby league players. Journal of Strength and Conditioning Research 13.3 230-235.

Bakos, F. (2007). Idegen szavak és kifejezések szótára (Dictionary of foreign words and phrases). Akadémiai Kiadó Zrt. Budapest. In Hungarian

Bangsbo, J., \& Mohr, M. (2012). Fitness testing in football Fitness training in soccer II.

Barnes, C. (2016). Making sense of athletes tracking data. International Congress on Football Science, Belek, Antalya. 
Beunen, G. (2003). Physical growth, maturation and performance. Revista Portuguesa de Ciencias do Desporto, $3,11-12$.

Bloomfield, J, Ackland, T., \& Elliott, B (1994). Applied Anatomy and Biomechanics in Sport. 1994 edn Blackwell Scientific Publications, Melbourne.

Bodzsár, É.B., \& Susanne, C. (1998). Secular growth changes in Hungary. In: É.B. Bodzsár \& C. Susanne (Eds.), Secular growth changes in Europe, (pp. 175-205). Budapest: Eötvös University Press.

Bompa, T.O., \& Carrera, M. (2015). Conditioning young athletes. Human Kinetics.

Buttifant, D., Graham, K., \& Cross, K. (2002). Agility and speed in soccer players are two different perfomance parameters. In: W. Spinks (Ed.). Science and football IV, (pp. 329-332). Routledge, London.

Chamari, K, Hachana, Y, Ahmed, Y.B., Galy,O., Sghaier, F., Chatard, J.C., et al. (2004). Field andlaboratory testing in young elite soccerplayers. Br J Sports Med., 38(2), 191-196.

Coelho e Silva, M.C., Figueiredo, A.J., Cumming, S.P., \& Malina, R.M. (2010). Discrimination of U-14 soccer players by level and position. International Journal of Sports Medicine, 31(11), 790-796.

Condello, G., Schultz, K., \& Tessitore, A. (2013). Assessment of sprint and change-of-direction perfomance in college football players. International Journal of Sports Physiology and Perfomance. 8(2), 211-212.

Csáki, I., \& Takács, M. (2020). Labdarúgás és tudomány (Football and science). Pro-Kvóta 2004 Kft. In Hungarian

Deprez, D., Fransen, J., Boone, J., Lenoir, M., Philippaerts, R., \& Vaeyens, R. (2015). Characteristics of highlevel youth soccer players. Variation by playing position. Journal of Sports Sciences, 33(3), 243-254.

di Cagno, A., Battaglia, C., Fiorilli, G., Piazza, M., Giombini, A., Fagnani, F., et al. (2014). Motor learning as young gymnast's talent indicator. Journal of Sports Science and Medicine, 13, 767-773.

Draper, J.A., \& Lancaster, M.G. (1985). The 505 test. A test for agility in the horizontal plane. Australian Journal of Science and Medicine in Sport, 17(1), 15-18.

Eiben, O., \& Pantó, E. (1981). A magyar ifjúság biológiai fejlodésének áttekintése. Adatok az ifjúságpolitika természettudományos megalapozásához (An overview of the biological development of Hungarian youth. Data for the scientific basis of youth policy). Humanbilogia Budapestinensis, 1 (Suppl.). In Hungarian

Farmosi, I., \& Bakonyi, F. (1987). A kondicionális képességek szekuláris változásai. Testnevelés-és Sporttudomány, 3, 20-26. In Hungarian

Fiorilli, G., Iuliano, E., Aquino, G., Battaglia, C., Giombini, A., Calcagno, G., et al. (2013). Mental health and social participation skills of wheelchair basketball players: a controlled study. Research in Developmental Disabilities, 34(11), 3679-3685.

Franks, I., \& Hughes, M. (2016). Soccer analytics. Meyer and Meyer Sport.

Gambetta, V. (1996). In a blur. How to develop sport-specific speed. Sports Coach, 19(3), 22-24

Goodman, C. (2008). Improving agility techniques. NSCA'S Perfomance Training Journal, 7(4), 10-12.

Gyenis, Gy. (1975). Az akceleráció és a civilizációs ártalmak (Acceleration and the harms of civilization). Antropologiai Közlemények, 19, 129-131. In Hungarian

Katics, L. (2015). Kondicionális és koordinációs képességek fejlesztése (a testnevelésben, szabadidö- és versenysportban).PTE TTK. Pécs. 259-271.

Kiitam, U., Voitkevica, L., Timpmann, S., Pontaga, I., Ereline, J., Unt, E., et al. (2018). Pre-practice hydration status in soccer players in cool environment. Medicina, 54(6), 102.

Koltai, M. (2018). Az agilitás mint a „többszintü” motorikus képességek újszerű értelmezése (Agility as a novel interpretation of "multilevel" motor abilities). In: Ihász Ferenc (Ed.). Egészségnevelés. Egészségmegörzésprevenció-a terhelésélettan alapjai (Health education. Health maintenance-Prevention-The basics of exercise physiology). Budapest: Akadémiai Kiadó. In Hungarian

Koltai, M., Gusztafik, Á., Nagyváradi, K., Szeiler, B., Halasi, Sz., \& Ihász, F. (2017). Examination of agility factors of junior football players in Bačka Topola, Serbia. International Journal of Sports Sciences and Physical Education, 2(1), 1-18

Koltai, M., Wallner D., Gusztafik, Á., Sáfár, Z., Dancs, H., Simi H., et al. (2016). Measuring of sport specific skills of football players. Journal of Human Sport and Exercise. University of Alicante. 11, 218-227.

Lacome, M., Simpson, B.M., Cholley, Y., Lambert, P., \& Buchheit, M. (2018). Small-sided games in elite soccer: Does one size fit all? International Journal of Sports Physiology and Performance, 13(5), 568-576.

Lohman, T.G. (1992). Advances in body composition assessment. Human Kinetics Publishers, Champaign, Illinois.

Mészáros, J., Othman, M., \& Szabó, T. (2001). Anthropometry and motor performance scores in Hungarian schoolboys. A 25 years comparison. In: J. Hank (Ed.), The exchange and development of sport culture in east and west, (pp. 102-103). Taipei: NTNU-AIESEP.

Milanović, Z., Sporiš, G., Trajković, N., Sekulić, D., James, N., \& Vučković, G. (2014). Does SAQ training improve the speed and flexibility of young soccer players? A randomized controlled trial. Human Movement Science 38. 197-208. 
Momčilović, Z., Marković, S., Bogavac, D., Milosavljević, T.D., \& Bugarski, S. (2020). Motor skills of soccer players aged 16-18 in regard to competition level and playing position. Facta Universitatis Series Physical Education and Sport, 18(1), 49-63.

Nagyváradi, K. (2017). Egészségiállapot-vizsgálat egy krónikus pszichiátriai betegeket gondozó intézmény szakdolgozóinak körében (Health examination among professionals in an institution caring for chronic psychiatric patients). Self Edition of Author. In Hungarian

Németh, A., \& Költő, Á. (2014). Egészség és egészségmagatartás iskoláskorban. Az Iskoláskorú gyermekek egészségmagatartása elnevezésü, az Egészségügyi Világszervezettel együttmüködésben megvalósuló nemzetközi kutatás 2014. évi felméréséröl készült nemzeti jelentés (Health and health behavior in school. National report on the 2014 survey of International Research on the Health Behaviors of School-Age Children, carried out in collaboration with the World Health Organization). National Institute for Health Development, Budapest. In Hungarian

[37] Németh, Zs. (2015). A labdarúgás technikai mozgásanyagának oktatás módszertani javaslatai. PTE TTK Sporttudományi és Testnevelési Intézet. Pécs.

Perroni, F., Vetrano, M., Camolese, G., Guidetti, L., \& Baldari, C. (2015). Anthropometric and somatotype characteristics of young soccer players. Differences among categories, subcategories, and playing position. The Journal of Strength and Conditioning Research, 29(8), 2097-2104.

Photiou, A., Anning, J., Mészáros, J., Vajda, I., Mészáros, Zs., Sziva, Á., et al. (2008). Lifestyle, body composition and physical fitness changes in Hungarian school boys (1975-2005). Research Quarterly for Exercise and Sport, 79, 168-173.

Post, G.B., Kemper, H.C.G., \& Twisk, J.W.R. (1997). Biological maturation in relation to lifestyle from adolescence into adulthood. In: N. Armstrong, B.J. Kirby, \& J.R. Welsman (Eds.). Children and exercise, (pp. 57-62), London: SPON.

Prókai, A., Völgyi, E., Mészáros, Zs., Tatár, A., Zsidegh, M., Uvacsek, M., et al. (2005). Relatív testzsírtartalom és motorikus teljesítmény (Relative body fat content and motor performance). In: A. Mónus, A. (Ed.). 4 Országos Sporttudományi Kongresszus II (4 National Sports Science Congress II), (pp. 238-243). Budapest: MSTT. In Hungarian

Purcell, L.K. (2013). Sport nutrition for young athletes. Paediatrics and Child Health, 18(4), 200-202.

Radák, Zs. (2019). Edzésélettan. Krea-Fitt Kft. In Hungarian

Rebelo, A., Brito, J., Maja, J., Coelho-Silva, M.J., Figuerido, A.J., Bangsbo, J., et al. (2013). Anthropometric chacaracteristics, physical fitness, and technical performance of Under-19 soccer players by competitive level and field position. International Journal of Sports Medicine, 34(4), 312-317

Reilly, T., Bangsbo, J., \& Franks, A. (2000). Anthropometric and physiological predispositions for elite soccer. Journal of Sports Sciences, 18, 669-683.

Rouissi, M., Chtara, M., Owen, A., Chaalali,A., Chaouachi , A., Gabbett, T., et al. (2006). Effect of leg dominance on change of directionability amongst young elite soccerplayers. Journal of Sports Sciences, 34(6), 542-548.

Rowland, T.W. (2005). Children's exercise physiology. Human Kinetics Publishers, Inc., Champaign, Illinois.

Ruas, C.V., Pint, M.D., Brown, L.E., Minozzo, F., Mil-Homens, P., \& Pinto, R.S. (2015). The association between conventional and dynamic control knee strength ratios in elite soccer players. Isokinetics and Exercise Science, 23(1), 1-12.

Sever,O., \& Zorba, E. (2017). Investigation of physical fitness levels of soccer players according to position and age variables. Facta Universitatis Series Physical Education and Sport, 15(2), 295-307.

Sheppard, J.M., \& Young, W.B. (2006). Agility literature review. Classifications, training and testing. Journal of Sports Sciences, 24, 919-932.

Sporiš, G., Jukić, I., Ostojić, S.M., \& Milanović, D. (2009). Fitness profiling in soccer. Physical and physiologic characteristics of elite players. Journal of Strength Conditioning Research, 23, 1947-1953.

Sporiš, G., Jukić, I., Milanović, L., \& Vučetić, V. (2010). Reliability and factorial validity of agility test for soccer players. Journal of Strength and Conditioning Research, 24(3), 679-686.

Steffl, M., Kinkorova, I., Kokstejn, J., \& Petr, M. (2019). Macronutrient intake in soccer players-a metaanalysis. Nutrients, 11(6), 1305.

Szakály, Zs. (2008). Testalkat, testösszetétel és motorikus teljesítményjellemzők vizsgálata (Examination of physique, body composition and motor performance characteristics). Doctoral Dissertation. Budapest: Semmelweis Egyetem, Testnevelési és Sporttudományi Kar. In Hungarian

Webb, P., \& Lander, J. (1983). An economical fitness testing battery for high school and college rugby teams. Sport Coach, 7(3), 44-46.

Young, W.B, Dawson, B., \& Henry, G.J. (2015). Agility and change-of-direction speed are independent skills. Implications for training for agility in invasion sports. International Journal of Sports Science and Coaching. 10(1), 159-169 
Young, W.B., James, R., Montgomery J.I. (2002). Is muscle power related to running speed with changes of direction? Journal of Sports Medicine and Physical Fitness, 42(3), 282-288.

Young, W.B., \& Willey B., (2010). Analysis of a reactive agility field test. Journal of Science and Medicine in Sport, 13(3), 376-378.

Young, W.B., Hawken, M., \& McDonald, L. (1996). Relationship between speed, agility and strength qualities in Australian Rules football. Strength and Conditioning Coach, 4(4), 3-6.

\section{POVEZANOST IZMEĐU AGILNOSTI IGRAČA FUDBALA ADOLESCENATA I NJIHOVE TELESNE KOMPOZICIJE}

Cilj ove studije je da se utvrde faktori telesne kompozicije (TK) koji utiču na agilnost fudbalera adolesxenata (N=66), u fudbalskim timovima U14, U16, U18, fudbalskog kluba Topola. Testovi agilnosti (Dribbling test, Illinois test) $i$ instrument Inbody 720 za merenje telesne kompozicije i Oka Starter infracrveni merni instrument za merenje brzine agilnosti korišćeni su u ovoj studiji. Podaci su obrađeni softverom IBM SPSS Statistics 25. Pored deskriptivne statistike, primenjene su i korelaciona matrična analiza, linearna regresija i jednosmerna analiza varijanse $(A N O V A)(p<0.05)$. Utvrđena je umerena korelacija između agilnosti sa loptom $i$ bez lopte $(r=0.595)$, kao $i$ između agilnosti $i$ parametara telesne kompozicije: Mišićna masa skeleta, Unutarćelijska masa vode, Masa proteina, Mineralna masa ( $r=-0,453,-0,454,-0,453,-0,417$, tim redosledom) dok korelacija između agilnosti $i$ Visine, Masa, Indeks telesne mase, Nemasna masa desne noge, Nemasna masa leve noge, Vanćelijska vodena masa, jeste manja od umerene ( $r=-0,318,-0,329,-0,276,-0,332,-0,330,-0,374$, tim redosledom). Utvrđena je blaga korelacija između agilnosti sa loptom i parametara telesne kompozicije. Nije utvrđena korelacija između, agilnosti i mase telesne masti. Uticaj telesne kompozicije na agilnost je manji od očekivanog. Korišćenjem naučno zasnovanog pristupa i merenja može se napraviti složen plan vežbanja za igrače i na taj način može da se sprovede obuka mladih fudbalera prilagođenim $i$ posebno utvrđenim metodama treniranja.

Ključne reči: agilnost, adolescenti, fudbal, kompozicija tela. 